\title{
Sistem Informasi Penyedia Layanan Kursus di Kota Palembang
}

\author{
Fandi Kurniawan $^{1}$, Ruliansyah ${ }^{2}$, Muhamad Kadafi ${ }^{3}$ \\ fhandykoerniawan@ymail.com ${ }^{1}$, ruli@radenfatah.ac.id ${ }^{2}$, kadafi_uin@ radenfatah.ac.id $^{3}$ \\ ${ }^{1}$ Prodi Sistem Informasi, Fakultas Sains dan Teknologi, UIN Raden Fatah \\ ${ }^{2}$ Prodi Sistem Informasi, Fakultas Sains dan Teknologi, UIN Raden Fatah \\ ${ }^{3}$ Prodi Sistem Informasi, Fakultas Sains dan Teknologi, UIN Raden Fatah
}

Diterima: 09 Oktober 2018 | Direvisi: 18 Februari 2019 | Disetujui: 26 Juni 2019

(C) 2019 Program Studi Sistem Informasi Fakultas Sains dan Teknologi,

Universitas Islam Negeri Raden Fatah Palembang, Indonesia

\begin{abstract}
Abstrak: Dewasa ini, teknologi berkembang cepat. Trend terbarui, beberapa perusahaan menggunakan aplikasi berbasis internet untuk mendukung pemasaran produknya. Tidak hanya pada kegiatan promosi yang menampilkan produk supaya diketahui oleh para konsumennya, bahkan beberapa perusahaan menggunakan teknologi internet ini untuk mendukung kegiatan transaksi, misalnya penjualan produk kepada konsumennya. Penelitian ini bertujuan untuk merancang dan membangun Sistem Informasi Penyedia Layanan Kursus di Kota Palembang mengingat banyaknya lembaga kursus dan susahnya mencari lembaga kursus secara cepat, dan terpercaya di kota Palembang. Metode penelitian yang digunakan yaitu metode penelitian kualitatif dengan metode pengumpulan data yaitu observasi, wawancara, studi pustaka. Metode pengembangan sistem yang digunakan yaitu Prototype. Alat bantu analisis dan perancangan yang digunakan yaitu Unified Modeling Language (UML), Bahasa pemrograman yang digunakan yaitu Hypertext Preprocessor (PHP), framework Codeigniter, serta database menggunakan MySQL, Metode pengujian menggunakan Graphical User Interface (GUI). Diharapkan sistem menjadi mesin pencari kursus di Kota Palembang.
\end{abstract}

Kata Kunci: Sistem Informasi Penyedia Layanan, Penyedia Layanan Kursus, Berbasis Web

\begin{abstract}
These day, technology grow up so fast. The newest trend, some companies using application based internet for supporting their product marketing. Not only using for promotion activity that showed up their product in order to knowed by their consumer, but also some other companies using internet technology for supporting transaction activity, for example, to easier product sell to their consumer. This research is aimed to designing and contracting information systems for course service provider in Palembang. In case there are so many course provider in Palembang and it's difficult enough to found a course provider fastly that has a good credibility in Palembang. The data in this research is collected using qualitative approach with observation, interview, and literature study. This research also using prototype for developing system method. Analysis and design tools that used is Unified Modeling Language (UML), Programming language using Hypertext Preprocessor (PHP), framework Codeigniter, and database using MySQL, and testing method using Graphical User Interface (GUI). Hopefully this system could be the best course search engine in Palembang.

Keywords: Information Systems Service Provider, Course Service Provider, Web-based
\end{abstract}

\section{PENDAHULUAN}

Di Indonesia perkembangan E-Commerce mengalami kemajuan yang pesat. Kepercayaan masyarakat pun semakin meningkat dengan keamanan dan kemudahan yang didapat dari penggunaan layanan E-Commerce. Hasil survei yang dilakukan oleh Ipsos (perusahaan riset pasar independen yang dikelola oleh periset profesional, didirikan di Perancis kini memiliki kantor di 84 negara) pada tahun 2012 menunjukkan bahwa 69\% pengguna Internet di Indonesia melakukan pencarian web untuk mencari produk yang ingin mereka beli, serta dari jumlah total responden sebanyak tersebut $48 \%$ melakukan pembelian barang secara online. 
Penyedia layanan kursus di Kota Palembang merupakan solusi untuk memberikan kemudahan dalam melakukan transaksi pembayaran dan pendaftaran kursus. Sangat penting untuk mengetahui apa itu E-Commerce sebagai penyedia layanan dan apa saja yang dapat kita lakukan dengan E-Commerce tersebut sehingga kita memanfaatkannya secara maksimal (Marjito, M., \& Gina, T., 2016). Kemudahan yang hanya membuka smartphone maka semua transaksi dilakukan dengan mudah. Perkembangan e-commerce di Kota Palembang mulai bermunculan. Dengan hal ini pentingnya sistem informasi penyedia layanan di Kota Palembang, mengingat banyaknya lembaga kursus dan susahnya mencari penyedia jasa kursus secara cepat dan terpercaya. Maka diperlukannya sistem informasi penyedia jasa yang memberikan solusi yang dapat mengelola penyedia kursus dengan klasifikasi daerah, kelas dan bidang kursus di Kota Palembang.

\section{METODOLOGI PENELITIAN}

\subsection{Landasan Teori}

\subsubsection{Pengertian Data}

Merupakan sesuatu yang belum mempunyai arti bagi penerimanya dan masih memerlukan adanya suatu pengolahan. Data bisa berwujud suatu keadaan, gambar, suara, huruf, angka, matematika, bahasa ataupun simbol-simbol lainnya yang bisa kita gunakan sebagai bahan untuk melihat lingkungan, objek, kejadian ataupun suatu konsep (Iswandy, 2015).

\subsubsection{Pengertian Sistem Informasi}

Menurut Jogiyanto di dalam (Novita \& Sari, 2015) menjelaskan bahwa sistem merupakan suatu grup dari elemen-elemen baik berbentuk fisik maupun bukan fisik yang menunjukkan suatu kumpulan saling berhubungan diantaranya dan berinteraksi bersama-sama menuju satu atau lebih tujuan, sasaran atau akhir dari sistem. Sedangkan informasi merupakan data yang diolah menjadi bentuk yang lebih berguna dan lebih berarti bagi yang menerima (Novita \& Sari, 2015).

\subsection{Identifikasi Permasalahan}

Adapun Beberapa temuan permasalahan yang terdapat pada sistem yang sedang berjalan dapat diuraikan permasalahan, penyebab permasalahan dan titik keputusan dari permasalahan seperti yang ditampilkan pada Tabel 1 .

Tabel 1. Identifikasi Permasalahan

\begin{tabular}{|l|l|c|}
\hline \multicolumn{1}{|c|}{ Masalah } & \multicolumn{1}{|c|}{ Penyebab Masalah } & Keterangan \\
\hline $\begin{array}{l}\text { Pencarian lembaga } \\
\text { yang susah ditemukan }\end{array}$ & $\begin{array}{l}\text { Proses promosi dilakukan } \\
\text { dengan brosur dan belum } \\
\text { dilakukan secara online }\end{array}$ & Bagian promosi \\
\hline $\begin{array}{l}\text { Pendaftaran Kursus } \\
\text { yang merepotkan, } \\
\text { datang ke lokasi }\end{array}$ & $\begin{array}{l}\text { Proses pendaftaran kursus } \\
\text { masih berupa berkas dan } \\
\text { belum dilakukan secara } \\
\text { Online }\end{array}$ & Bagian registrasi \\
\hline $\begin{array}{l}\text { Penelusuran riwayat } \\
\text { peserta kursus sulit } \\
\text { dilakukan }\end{array}$ & $\begin{array}{l}\text { Penelusuran peserta kursus } \\
\text { yang belum tersedia }\end{array}$ & Bagian pengarsipan \\
\hline $\begin{array}{l}\text { Pembayaran yang } \\
\text { sering tidak } \\
\text { ditemukan }\end{array}$ & $\begin{array}{l}\text { Proses pembayaran yang } \\
\text { belum dilakukan secara } \\
\text { real time (e-banking) }\end{array}$ & Bagian pembayaran \\
\hline
\end{tabular}

Volume 5, Nomor 1, Juni 2019 


\subsection{Uraian Pemecahan Masalah}

Berdasarkan uraian identifikasi permasalahan maka dapat diuraikan pemecahan masalah yang didapatkan dari titik keputusan sehingga dapat diterapkan pada sistem yang dibangun seperti yang uraikan berikut ini:

1) Promosi dilakukan dengan sistem informasi berbasis web \& android.

2) Registrasi secara online dan booking otomatis pada aplikasi android.

3) Penelusuran peserta tersedia pada sistem yang menyimpan data dan informasi yang dibutuhkan.

4) Pembayaran yang dilakukan secara online e-banking dan dapat dilakukan dimana saja dengan mudah.

\subsection{Use case Diagram}

Perancangan pemodelan use case diagram pada penelitian ini dapat dilihat pada Gambar 1.

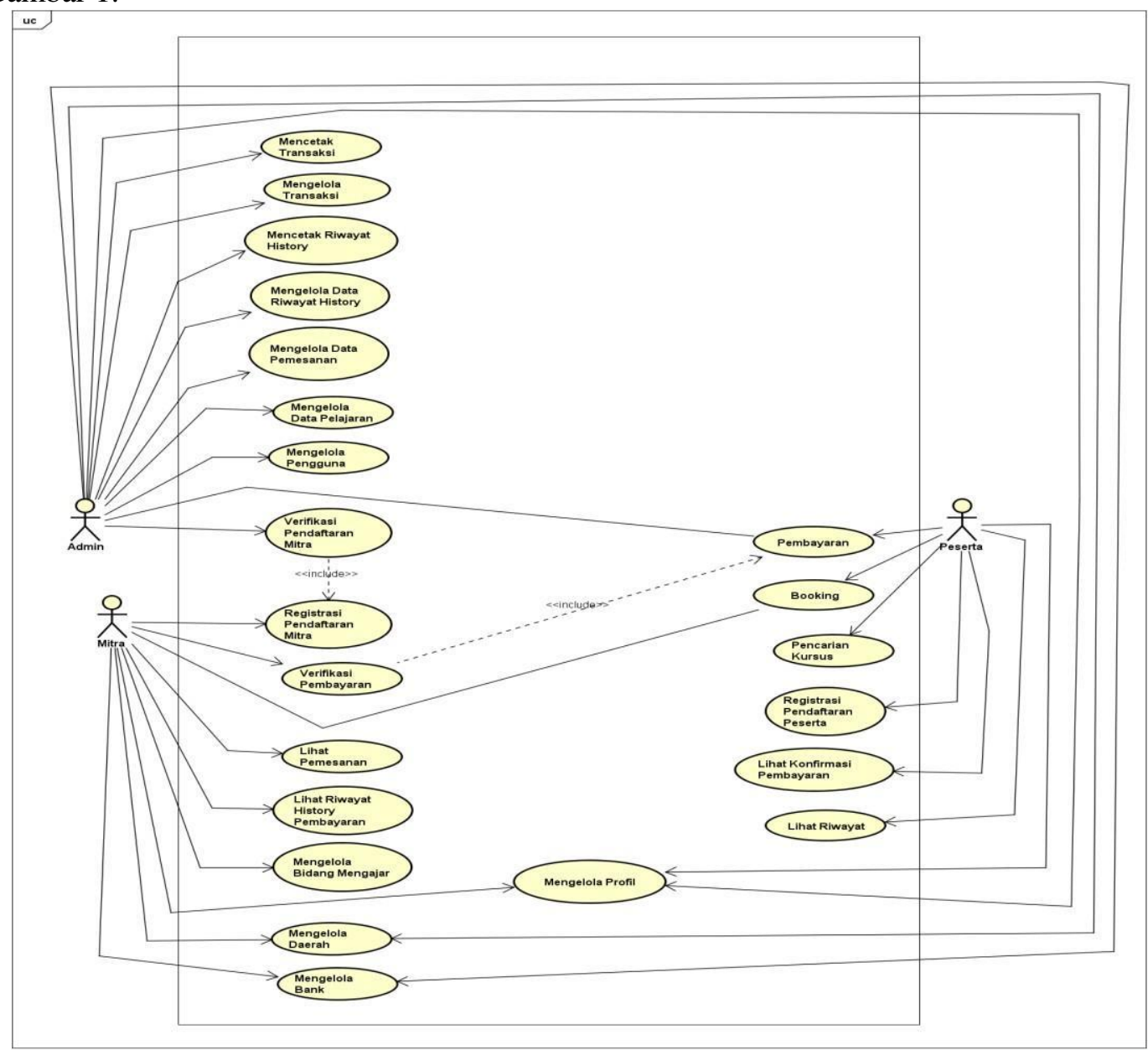

Gambar 1. Use case Diagram 


\subsection{Activity Diagram}

\subsubsection{Activity Diagram Administrator}

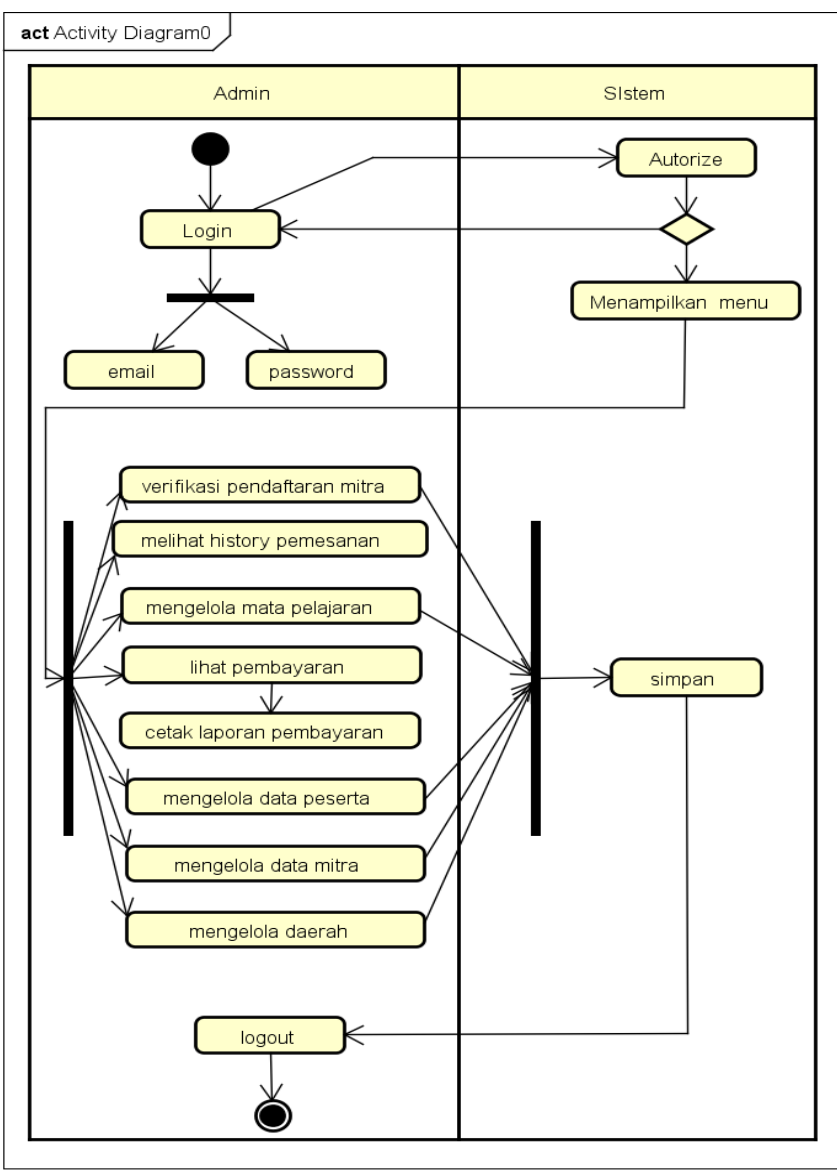

Gambar 2. Activity Diagram Administrator 


\subsubsection{Activity Diagram Mitra}

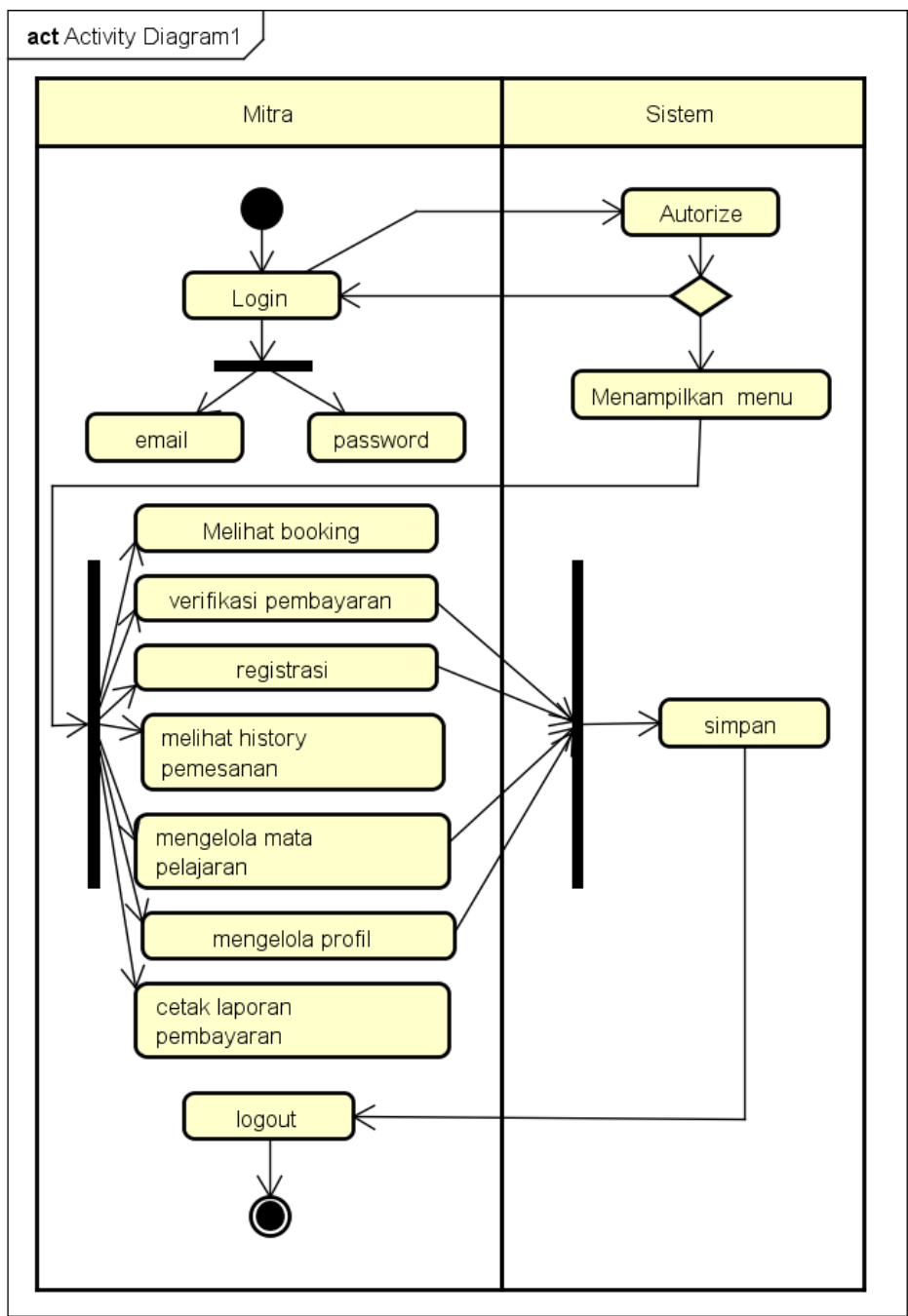

Gambar 3. Activity Diagram Mitra 


\subsubsection{Activity Diagram Peserta}

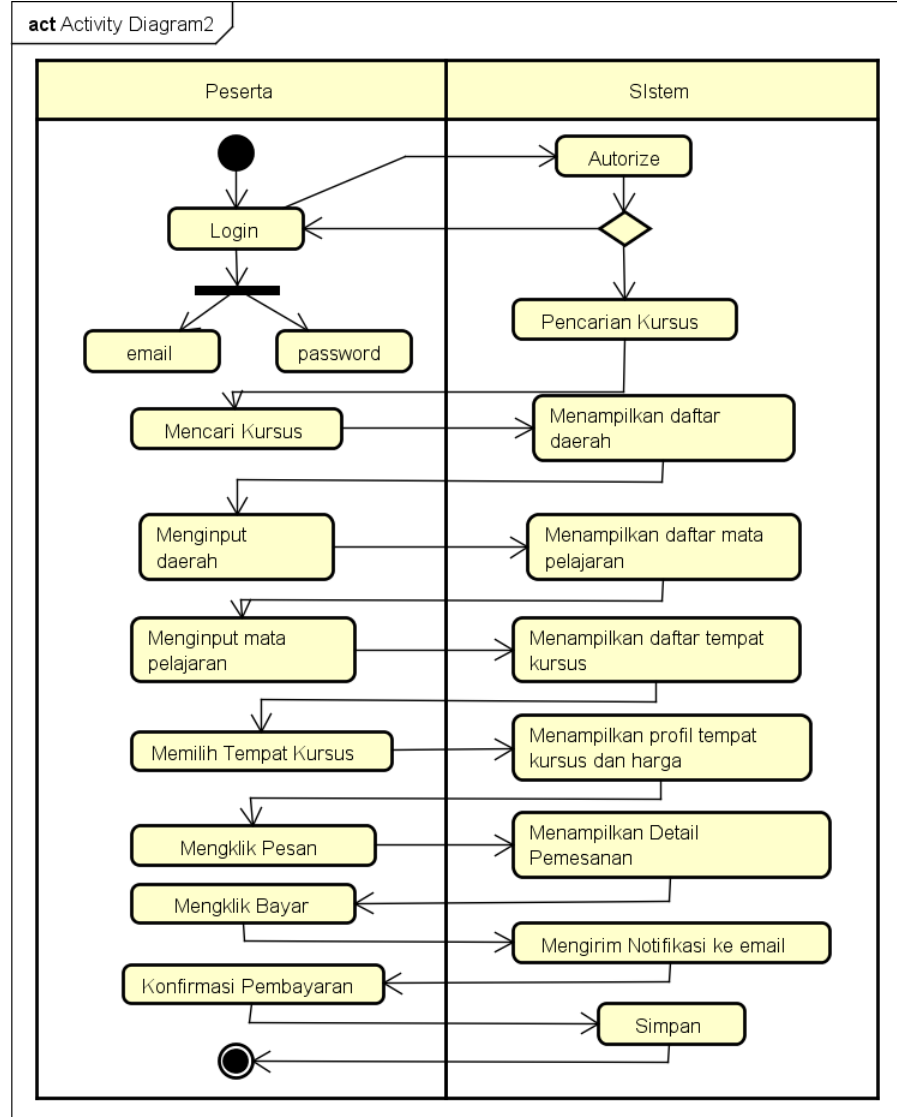

Gambar 4. Activity Diagram Peserta

\section{HASIL DAN PEMBAHASAN}

\subsection{Antarmuka pengguna (user-interface) SIP Layanan Kursus}

Tahapan konstruksi SIP Layanan Kursus dibagi menjadi dua jenis antarmuka tampilan yakni front-end interface (tampilan depan) dari SIP Layanan Kursus yaitu halaman publik yang akan ditampilkan secara otomatis ketika mengakses alamat URL dari SIP Layanan Kursus atau ketika pengguna sedang tidak dalam kondisi login. Back-end interface (tampilan belakang) dari SIP Layanan Kursus yaitu halaman terbatas yang hanya akan ditampilkan apabila pengguna dalam kondisi login ke SIP Layanan Kursus, dan dapat melakukan pengelolaan data sesuai dengan level hak akses dari pengguna.

\subsubsection{Antarmuka Tampilan Front-End SIP Layanan Kursus}

Adapun tampilan front-end dari SIP Layanan Kursus antara lain: Halaman utama, halaman kursus dan halaman daftar mitra kursus. 


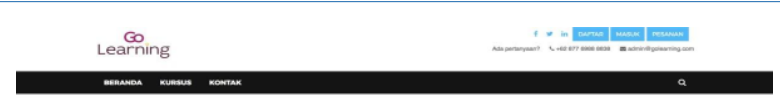

\section{dari yang anda bayangkan}

Go-Learning Sebagai Tempat Pencarian Kursus
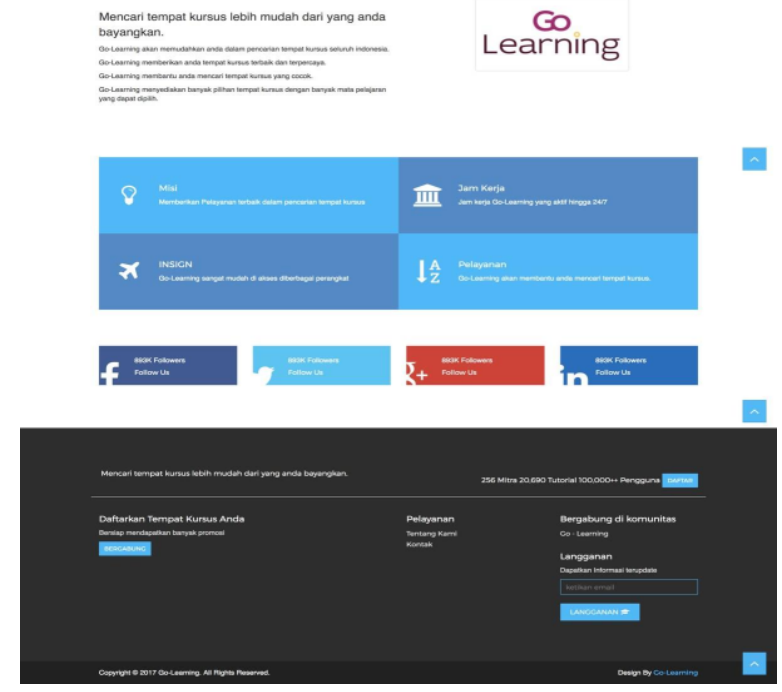

Gambar 5. Halaman Utama

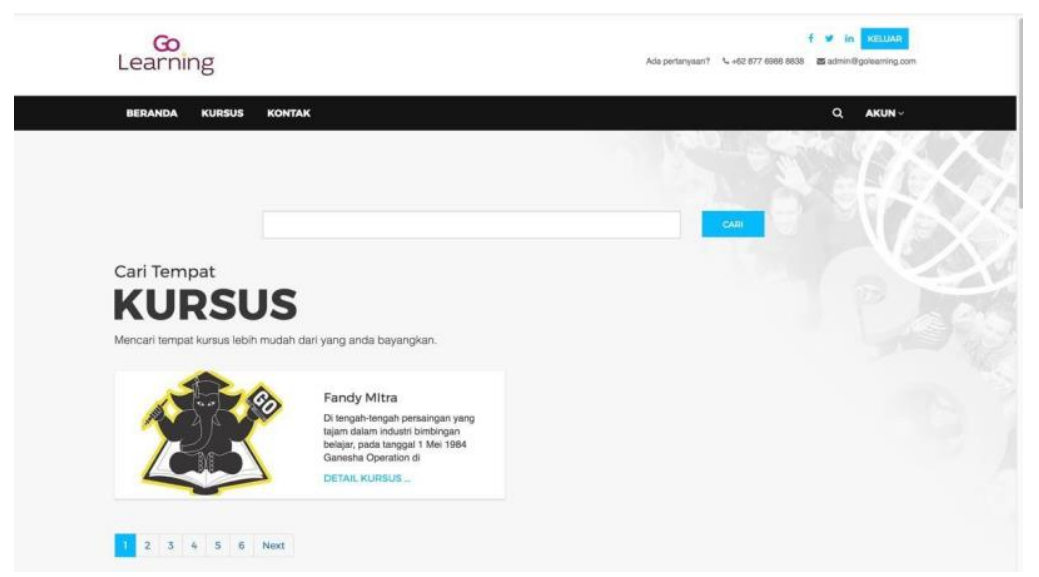

Gambar 6. Halaman Utama Kursus

Halaman utama kursus ini adalah menampilkan informasi layanan kursus mencakup nama lembaga kursus yang telah bermitra dengan SIP Layanan Kursus (Go Learning). Disertai juga navigasi untuk menuju detail informasi kursus secara lengkap sesuai dengan record database. Dengan header yang disertai menu navigasi untuk menuju ke halaman pencarian kursus, daftar menjadi mitra, dan halaman login serta terdapat navigasi sidebar untuk informasi pendukung. Bagian footer pada antarmuka frontend menampilkan informasi yang berkaitan dengan SIP Layanan Kursus ini.

\subsubsection{Antarmuka Tampilan Back-End SIP Layanan Kursus}

Adapun tampilan back-end dari SIP Layanan Kursus antara lain: Halaman utama, halaman pemesanan, pembelajaran dan halaman pengguna. Untuk tampilan interfacenya bisa dilihat pada gambar dibawah ini. 


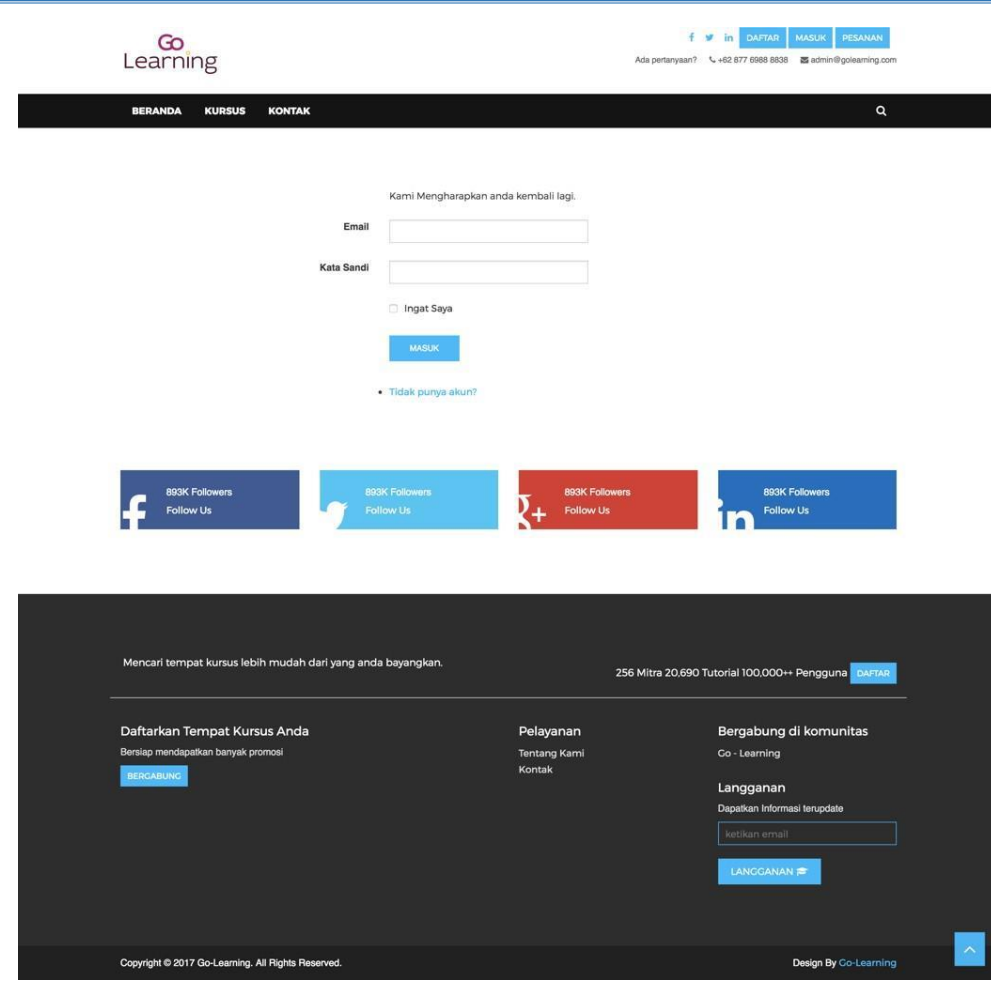

Gambar 7. Halaman Utama Login

Antarmuka tampilan halaman login yang terbagi menjadi hak akses level peserta, mitra dan admin. Setelah melakukan mengisi form login email dan password selanjutnya akan diproses dengan mengklik button login. Hasil masuk pada halaman yang tampil berdasarkan tingkat level manajemen akses masing-masing user.

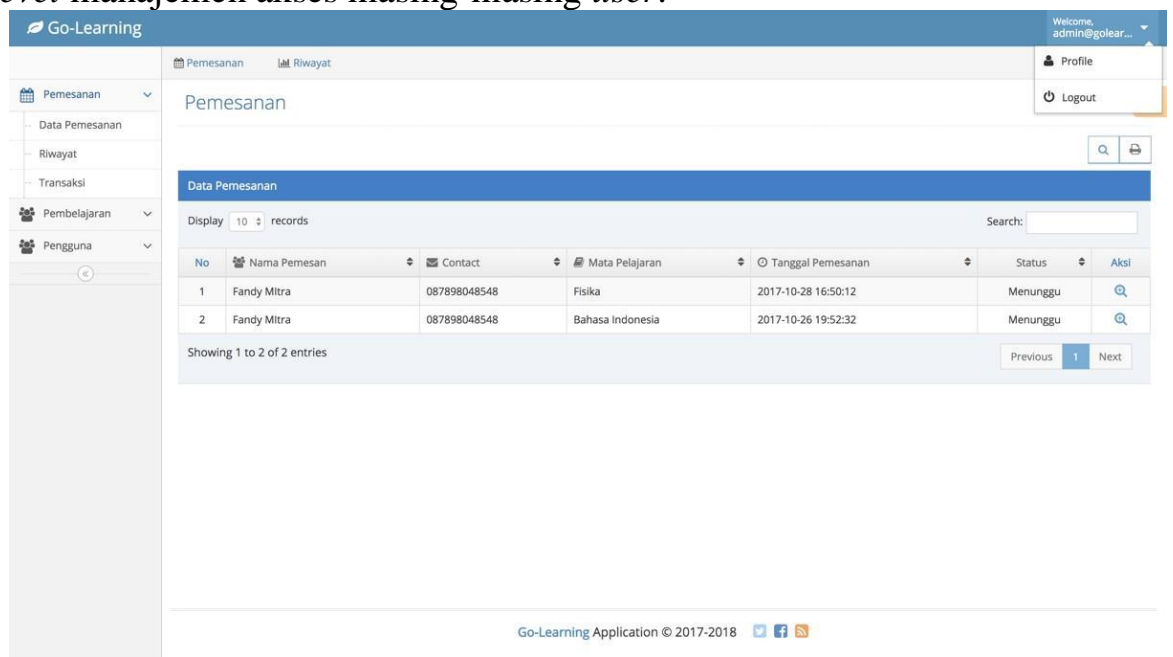

Gambar 8. Halaman Utama Pemesanan 


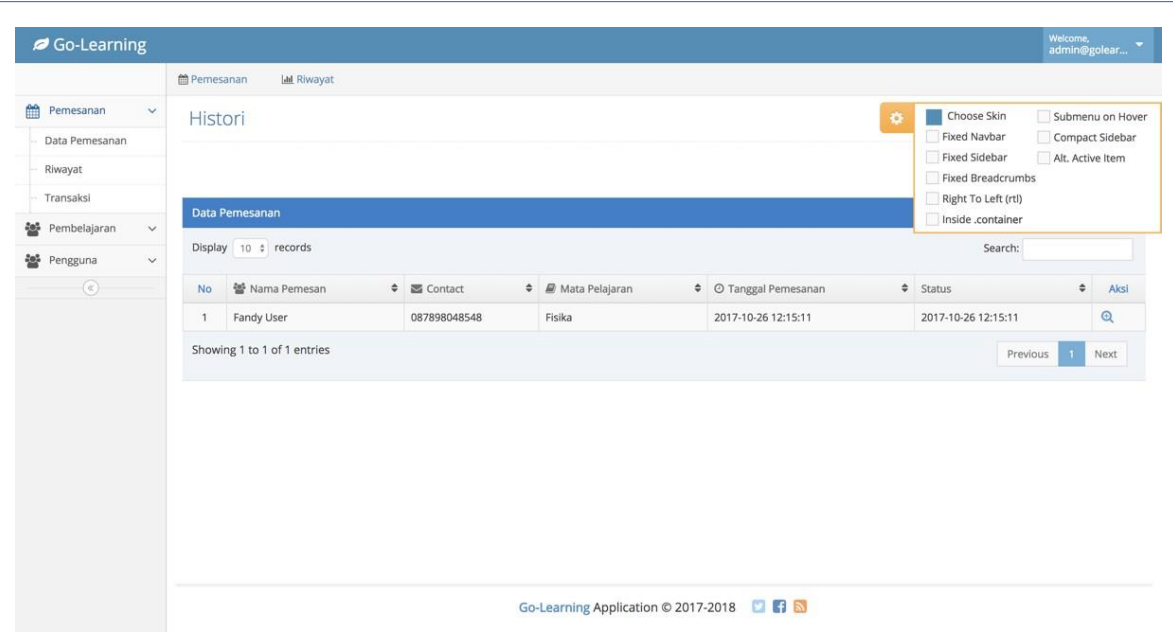

Gambar 9. Halaman Riwayat

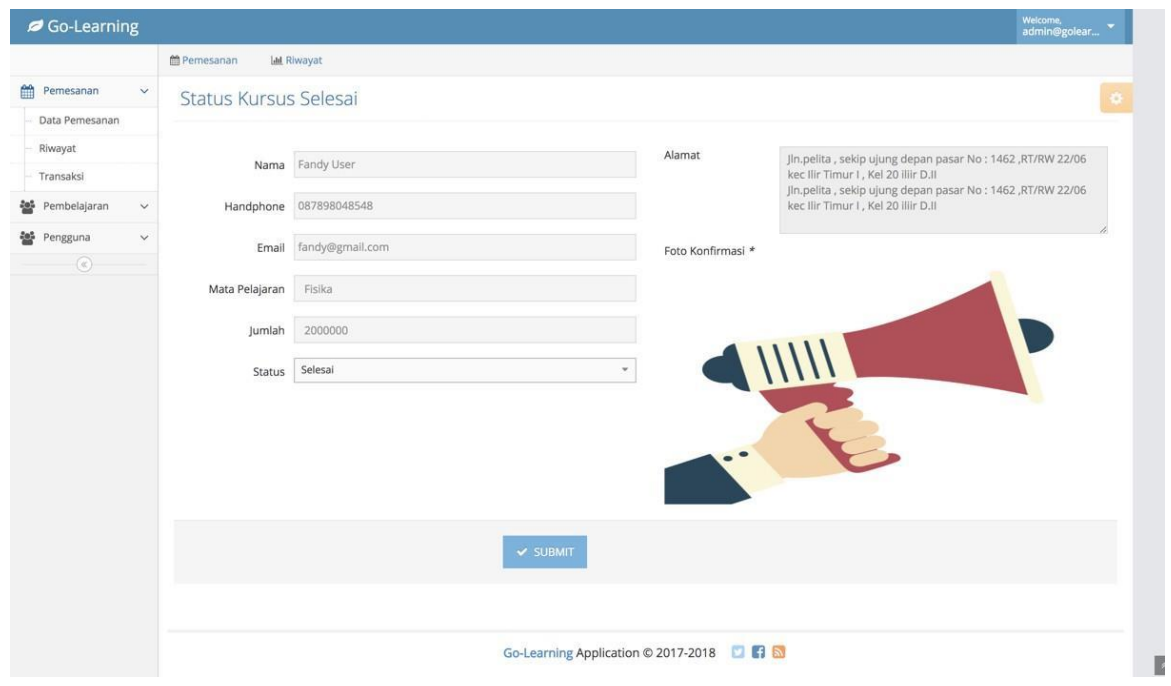

Gambar 10. Halaman Riwayat (Status Kursus)

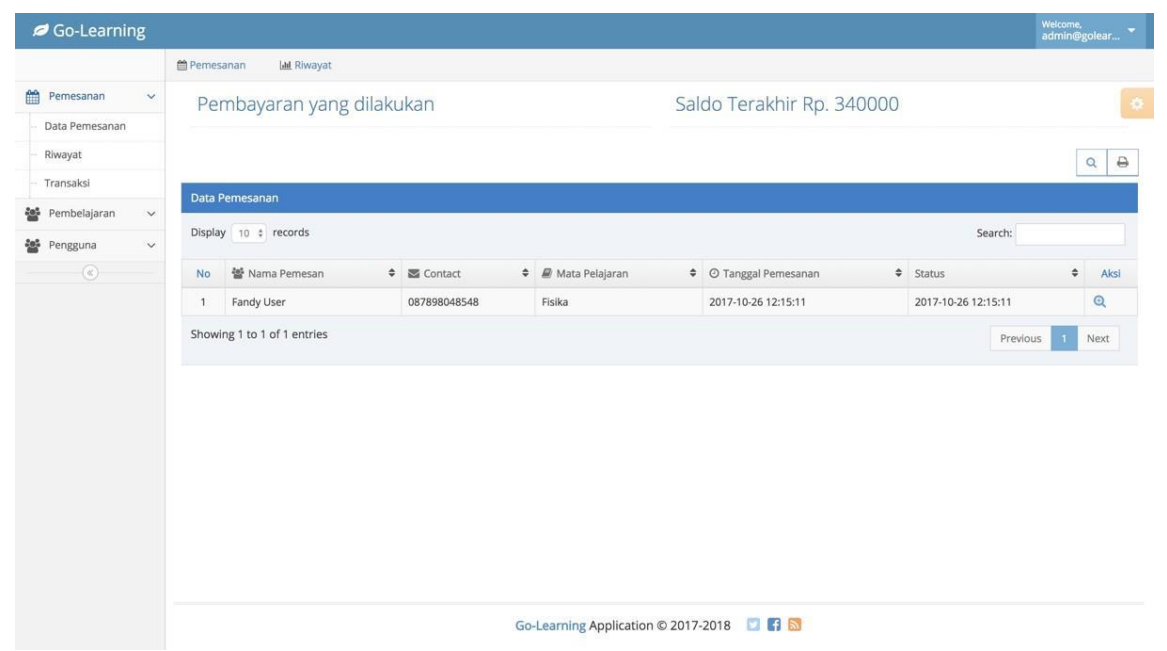

Gambar 11. Halaman Transaksi 


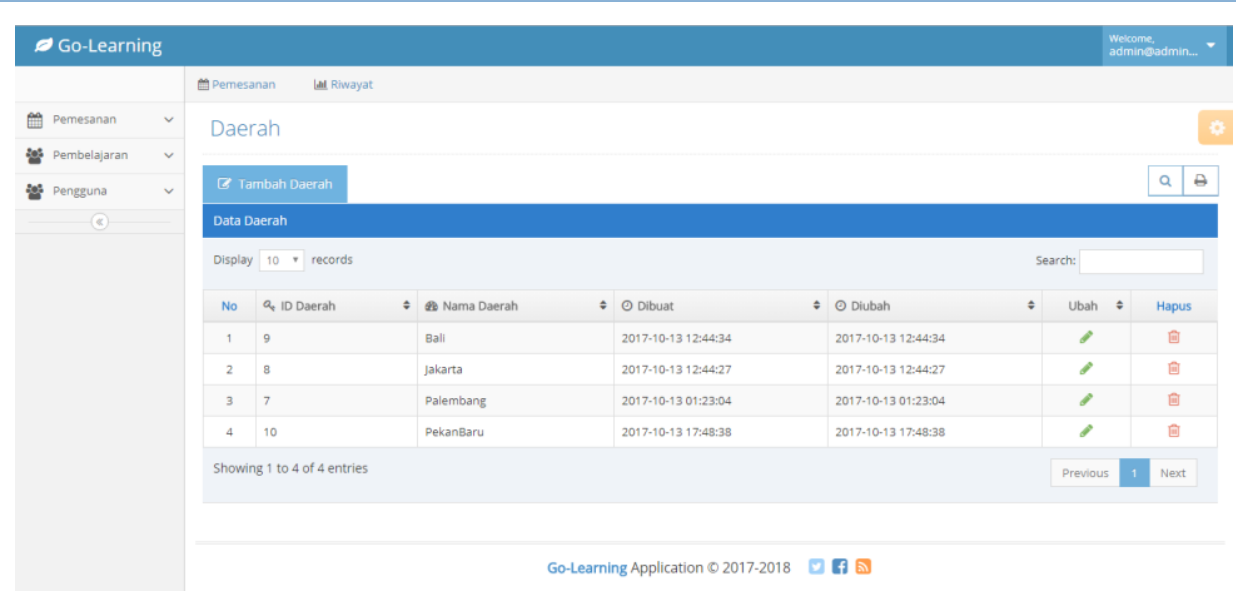

Gambar 12. Halaman Data Daerah

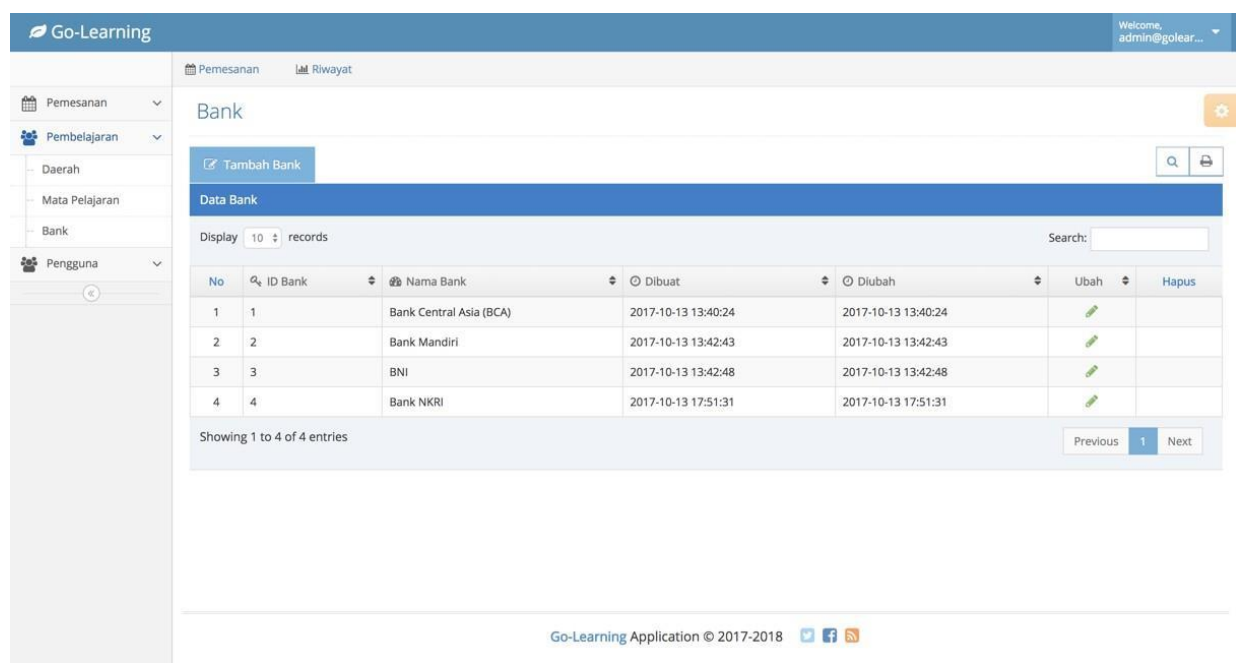

Gambar 13. Halaman Data Bank

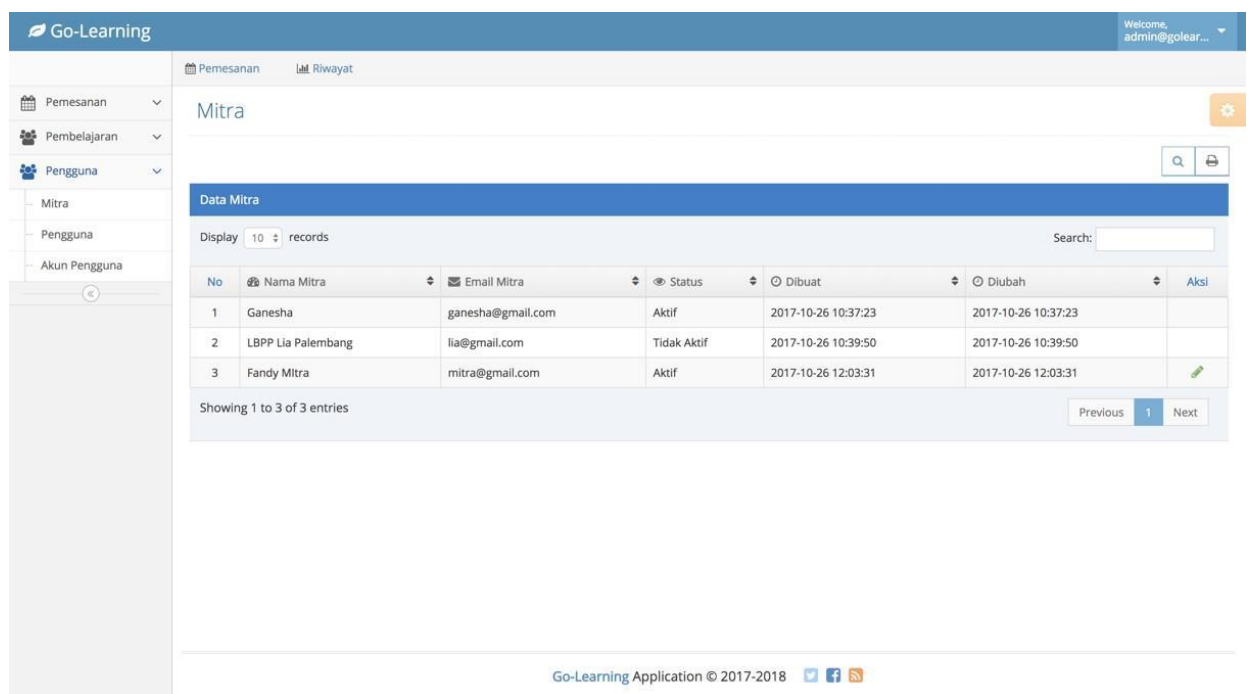

Gambar 14. Halaman Pengguna Data Mitra 


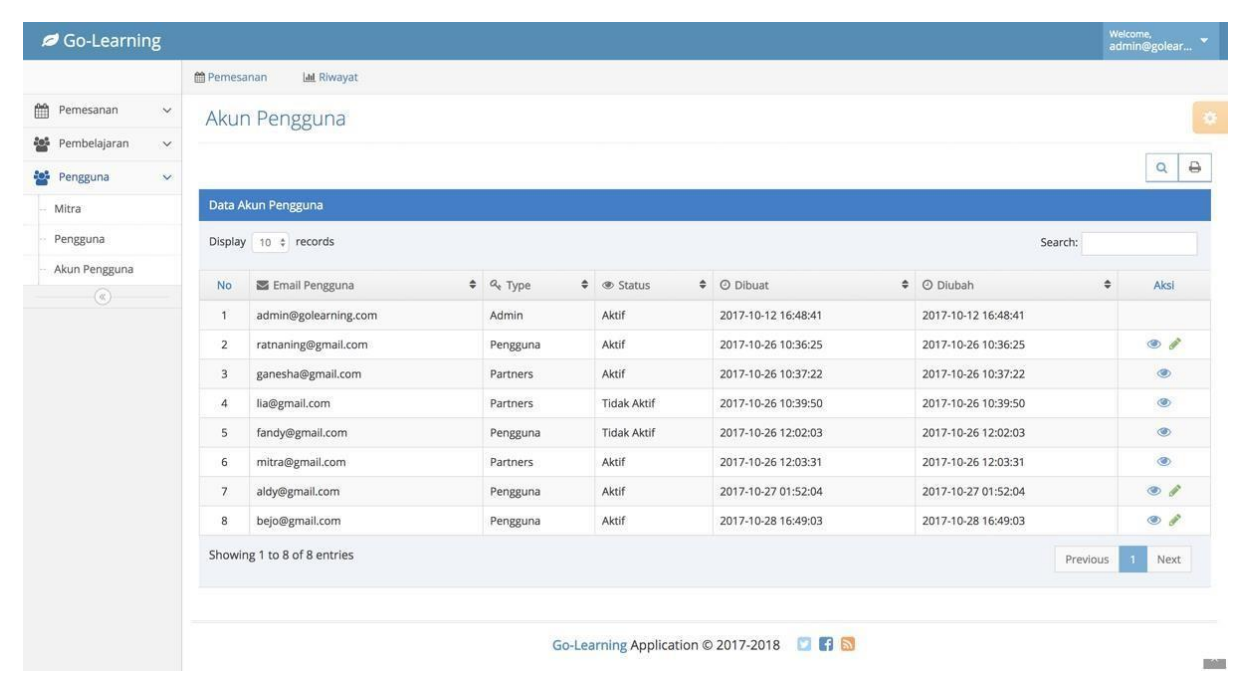

Gambar 15. Halaman Akun Pengguna

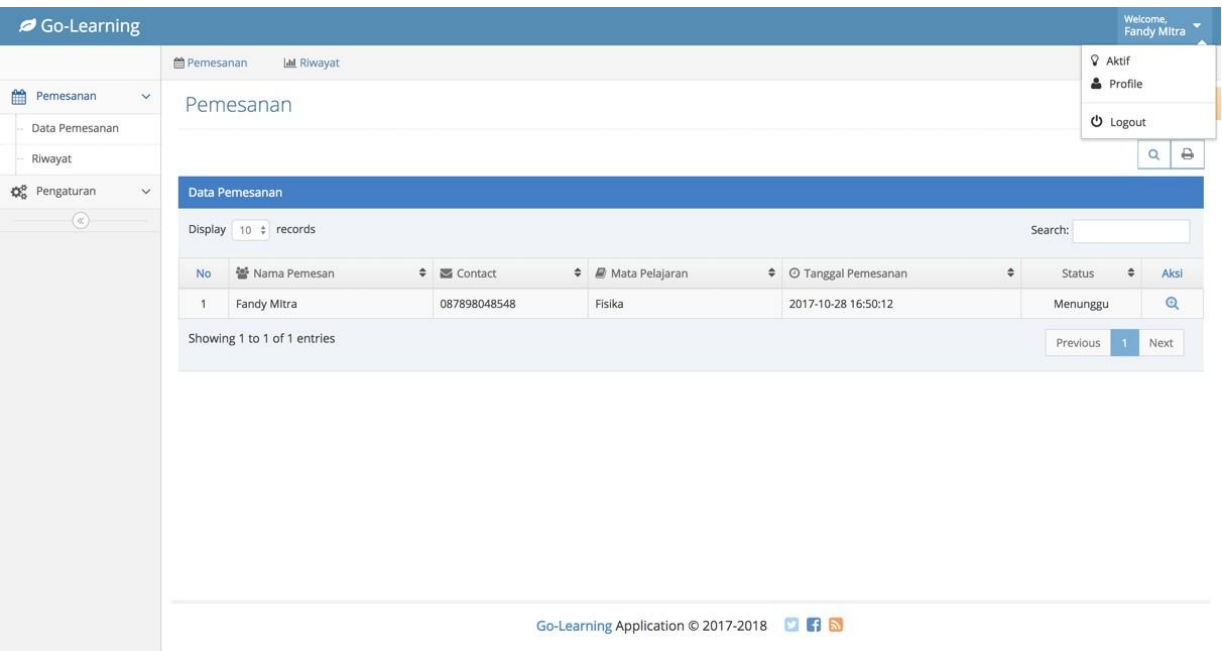

Gambar 16. Halaman Utama Mitra

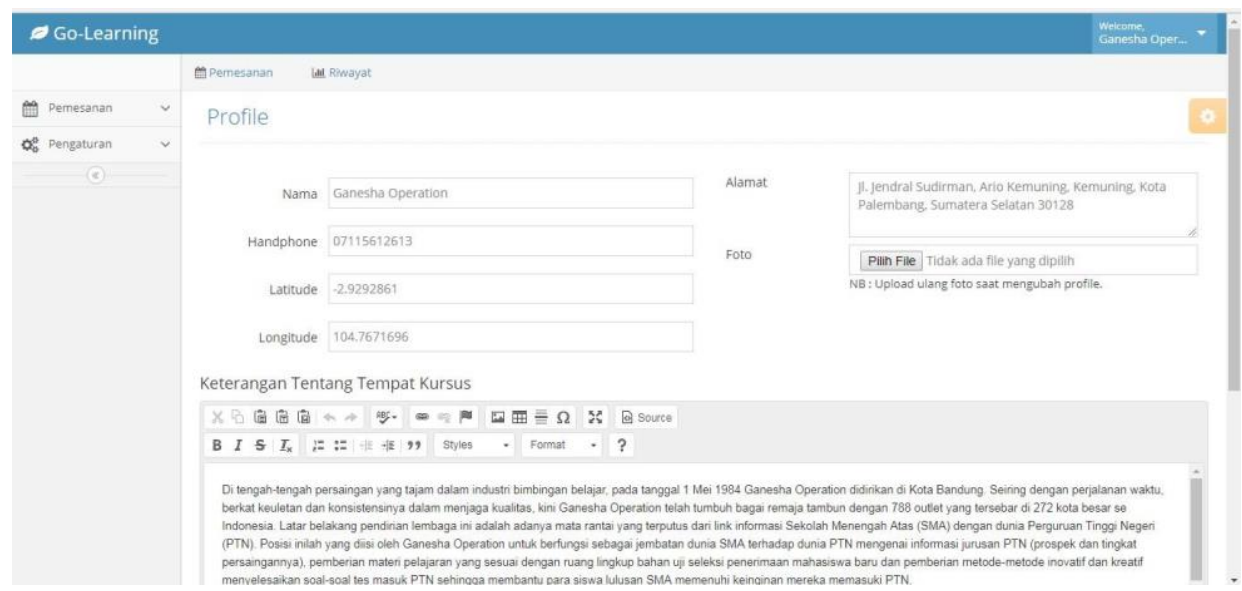

\section{Gambar 17. Halaman Data Pengguna}




\section{KESIMPULAN}

Berdasarkan hasil penelitian yang telah dilakukan maka dapat diambil beberapa kesimpulan, yaitu:

1. Memberikan peluang layanan baru dalam pendaftaran kursus.

2. Memberikan kemudahan dalam melakukan transaksi pembayaran.

3. Meringankan lembaga pendidikan dalam melakukan promosi dengan brosur, paper.

4. Memberikan kemudahan konsumen dalam melakukan pencarian daerah, tempat, dan penyedia kursus yang sesuai dengan spesifikasi budget yang diinginkan.

\section{DAFTAR RUJUKAN}

Iswandy, E. (2015). Sistem Penunjang Keputusan untuk Menentukan Penerimaan Dana Santunan Sosial Anak Nagari dan Penyalurannya Bagi Mahasiswa dan Pelajar Kurang Mampu di Kenagarian Barung - Barung Balantai Timur. Jurnal TeknoIF, 70-79.

Marjito, M., \& Gina, T. (2016). Aplikasi Penjualan Online Berbasis Android. Jurnal Computech \& Bisnis, 40-49.

Novita, R., \& Sari, N. (2015). Sistem Informasi Penjualan Pupuk Berbasis E-Commerce. Jurnal TeknoIF, 1-6. 